\title{
Retroperitoneal Abscess
}

National Cancer Institute

\section{Source}

National Cancer Institute. Retroperitoneal Abscess. NCI Thesaurus. Code C128330.

An abscess that is located in the abdominal cavity posterior to the peritoneum. 